\title{
European Porphyria Network (EPNET) for information, epidemiological data, quality and equity of service
}

\author{
Jean-Charles Deybach ${ }^{1}$, Samantha Parker ${ }^{2 *}$, Mike Badmiton ${ }^{3}$, Sverre Sandberg ${ }^{4}$ \\ From 5th European Conference on Rare Diseases (ECRD 2010) \\ Krakow, Poland. 13-15 May 2010
}

Porphyrias are metabolic diseases that affect about 1 in 20,000 of the EU population. Most healthcare professionals rarely encounter these disorders and there is disparity between countries in the levels of support provided for patients and their carers.

EPNET is a DG Sanco funded project (1/4/2007-31/3/ 2010) with 15 participating countries that aims to establish a network of specialist porphyria centres, each working to agreed quality criteria. Work achieved:

1. Information on porphyria for patients in 10 languages, and for healthcare professionals in English, is available at http://www.porphyria-europe.org with easily downloadable pdf files.

2. Data on the safety of drugs in acute porphyria has been collected from participating countries (2901 drug reports on 616 drugs). Information is disseminated on http://www.drugs-porphyria.org

3. European Quality Assessment (EQA) schemes have been established for specialist laboratories (24 participants in 17 countries) and data on laboratory performance collected annually. Variations between centres are being addressed and diagnostic protocols developed.

4. The EPNET registry now contains data on 371 patients (320 new cases; 51 with long term complications) that is being used to calculate the incidence of each porphyria in participating countries and the prevalence of long term complications, The incidence of new cases of acute intermittent porphyria is around $0.15 / \mathrm{mil}-$ lion/year in most countries.

The initial purposes of the EPNET project have been achieved; we have established a rich data resource, a

\footnotetext{
* Correspondence: sparker@orphan-europe.com

2EPNET Programme Manager, 70 avenue du Général de Gaulle, 92058

Puteaux La Défense, France

Full list of author information is available at the end of the article
}

network for improving quality of care and a European platform for expert exchange.

EPNET has been funded by the European Commission through its Public Health and Consumer Protection Directorate (DG SANCO), PHEA programme.

\section{Author details}

${ }^{1}$ Centre Francais des porphyries, INSERM U773, Hôpital Louis Mourier, 178 rue des Renouillers, Colombes, 92701, France. 'EPNET Programme Manager, 70 avenue du Général de Gaulle, 92058 Puteaux La Défense, France. ${ }^{3}$ Cardiff and Vale NHS Trust, University Hospital of Wales, Heath Park, Cardiff CF14 4XW, UK. ${ }^{4}$ Department of Public Health and Primary Health Care, University of Bergen, Postboks 7800, NO-5020 Bergen, Norway.

Published: 19 October 2010

doi:10.1186/1750-1172-5-S1-P16

Cite this article as: Deybach et al.: European Porphyria Network (EPNET) for information, epidemiological data, quality and equity of service. Orphanet Journal of Rare Diseases 2010 5(Suppl 1):P16.

Submit your next manuscript to BioMed Central and take full advantage of:

- Convenient online submission

- Thorough peer review

- No space constraints or color figure charges

- Immediate publication on acceptance

- Inclusion in PubMed, CAS, Scopus and Google Scholar

- Research which is freely available for redistribution

Submit your manuscript at www.biomedcentral.com/submit
Biomed Central 